\title{
KEKUATAN HUKUM EKSEKUSI JAMINAN AKTA PENGAKUAN HUTANG DALAM PERJANJIAN KREDIT (STUDI PENELITIAN DI PT. BANK MANDIRI KANTOR CABANG PEMBANTU MATANG GEULUMPANG DUA KABUPATEN BIREUEN ACEH)
}

\author{
ASMAUL HUSNA \\ Program Studi Magister Kenotariatan \\ Fakultas Hukum Universitas Sumatera Utara \\ Jalan Dr.T. Mansur Nomor 9, Kampus Padang Bulan, Medan \\ Telp.(061)8211633
}

\begin{abstract}
In banking practice, a loan is usually realized in form of an agreement of acknowledgment of debt by debtor to creditor, in which the creditor acknowledges to have made a loan of some amount of money to a bank, under particular terms. When a debtor defaults, a creditor can file a request to Head of Court for execution of the contents of their agreement with a grosse deed because it has executorial force. However, in this research, the creditor does not directly execute the guarantee when the debtor defaults. Instead, they issue a Letter of Declaration of Willingness to discharge the rights over the collateral that is guaranteed and signed by the debtor. The research problems are how about the legal force of execution of collateral in a deed of acknowledgement of debt in a loan agreement, how about the legal consequences for the debtor in the deed of acknowledgement of debt in case of a default in a loan agreement in Matang Geulumpang Dua Village, and how about the legal efforts that can be made by the creditor in the execution of the collateral in the deed of acknowledgment of debt in the loan agreement.
\end{abstract}

Keywords: $\quad$ Execution, Deed of Acknowledgment of Debt, Loan Agreement

\section{Intisari}

Dalam praktek perbankan suatu realisasi kredit biasanya dilakukan dalam bentuk perjanjian pengakuan hutang oleh debitur kepada kreditur, dimana debitur mengakui berhutang kepada bank sejumlah atau senilai uang tertentu, dengan jangka waktu tertentu. Dengan adanya grosse akta inilah maka apabila pihak debitur wanprestasi, maka pihak kreditur dapat mohon kepada Ketua Pengadilan untuk melaksanakan eksekusi terhadap isi perjanjian tersebut karena grosse akta memiliki kekuatan eksekutorial. Namun dalam penelitian ini, pihak kreditur tidak langsung melaksanakan eksekusi saat debitur wanprestasi. Pihak kreditur malah membuat Surat Pernyataan kerelaan pelepasan hak atas agunan yang dijaminkan tersebut dan ditandatangani oleh debitur. Tesis ini membahas Bagaimanakah kekuatan hukum eksekusi jaminan akta pengakuan hutang dalam perjanjian kredit, Bagaimanakah akibat hukum terhadap debitur dalam akta pengakuan hutang apabila terjadi wanprestasi pada perjanjian kredit dan Bagaimanakah upaya hukum yang dilakukan kreditur dalam eksekusi jaminan akta pengakuan hutang pada perjanjian kredit di desa Matang Geulumpang Dua. Jenis penelitian tesis ini menggunakan penelitian yuridis normatif yang bersifat deskriptif analitis. Data yang digunakan untuk menjawab permasalahan dalam penelitian ini adalah data sekunder dan data primer yang berasal dari penelitian kepustakaan 
dan lapangan. Hasil penelitian ini memberikan kesimpulan, Pihak kreditur atau Bank tidak langsung melakukan eksekusi terhadap jaminan akta pengakuan hutang tersebut, pihak Bank membuat surat pernyataan kerelaan pelepasan hak atas yang dijaminkan debitur tersebut dan meminta debitur untuk menandatangani surat tersebut.

Kata Kunci: Eksekusi, Akta Pengakuan Hutang, Perjanjian Kredit

\section{A. Latar Belakang}

Berdasarkan pada ketentuan Pasal 1754 KUHPerdata memakai istilah pinjam meminjam dan memberikan definisinya yaitu "suatu perjanjian dengan mana pihak yang satu memberikan kepada pihak yang lain suatu jumlah tertentu barang-barang yang habis karena pemakaian, dengan syarat bahwa pihak yang terakhir ini akan mengembalikan sejumlah yang sama dari jenis dan mutu yang sama pula. ${ }^{1}$ Utang piutang adalah suatu keadaan dalam hal mana salah satu pihak membutuhkan sejumlah uang dan pihak yang lain bersedia meminjamkan uangnya. ${ }^{2}$

Perjanjian pinjam-meminjam, hal ini sebagaimana diatur dalam Pasal 1754 KUHPerdata menyebutkan bahwa: ${ }^{3}$

"Pinjam-meminjam adalah perjanjian dengan mana pihak yang satu memberikan kepada pihak yang lain suatu jumlah terntentu barangbarang yang menghabis karena pemakaian, dengan syarat bahwa pihak yang belakangan ini akan mengembalikan sejumlah yang sama dari macam dan keadaan yang sama pula".

${ }^{1}$ R. Subekti, Aneka Perjanjian, Intermasa, Bandung, 1995, h. 125.

\footnotetext{
${ }^{2}$ Ibid.

${ }^{3}$ Pasal 1754 KUHPerdata.
}

Perjanjian pinjam-meminjam atau Perjanjian utang-piutang sebagai sebuah perjanjian menimbulkan hak dan kewajiban kepada kreditur dan debitur yang bertimbal balik. Inti dari perjanjian utang-piutang adalah kreditur memberikan pinjaman uang kepada debitur, dan debitur wajib mengembalikannya dalam waktu yang telah ditentukan disertai dengan bunganya. Pada umumnya, pengembalian utang dilakukan dengan cara mengangsur setiap bulan. ${ }^{4}$

Setelah perjanjian kredit biasanya akan diikuti dengan dibuatnya akta pengakuan hutang sebagai bentuk telah direalisasikannya kredit, yaitu penyerahan pinjaman (uang) secara riil oleh bank kepada debitur. Pengakuan hutang secara umum didefinisikan juga sebagai suatu pengakuan atas terjadinya suatu transaksi peminjaman sejumlah dana/uang. Akta Pengakuan Hutang dalam transaksi kredit ini merupakan dokumen penting yang berguna sebagai bukti pernah atau telah terjadi suatu hubungan hukum antara kreditur dengan debitur, hubungan hukum ini merupakan aspek hak dan kewajiban,

\footnotetext{
${ }^{4}$ Ibid., h. 146.
} 
sehingga menimbulkan prestasi dan sanksi terhadap kedua belah pihak. Hasil dari transaksi tersebut dituangkan dalam bentuk akta yang dinamakan Akta Pengakuan hutang. ${ }^{5}$

Akta pengakuan hutang merupakan suatu akta yang dibuat dalam bentuk notariil, dimana akta tersebut hanya memuat pengakuan hutang seseorang, berikut dengan jumlah hutang, suku bunga, jangka waktu, tempat pembayaran, hal-hal yang dapat menyebabkan hutang dapat ditagih atau dibayar seketika (opeisbaarheid), jaminan dan tidak disertai dengan persyaratan-persyaratan lain terlebih apabila persyaratan tersebut berbentuk perjanjian. ${ }^{6}$

Akta ini dapat dibuat di bawah tangan atau dengan akta autentik, dan dihadapan Notaris, dan dilengkapi dengan Grosse akta pengakuan hutang. ${ }^{7}$ Berdasarkan hukum acara perdata yang terdapat pada Herzien Inlandsh ReglementStb 1941 Nomor 44 (HIR) grosse akta diatur pada Pasal 224 HIR yang menyebutkan bahwa surat hipotik

5 Didi Santoso, "Tanggung Jawab Notaris Dalam Pembuatan Akta Yang Memuat Dua Perbuatan Hukum (Analisis Putusan Mhkamah Agung Nomor 1440.K/Pdt/1996)." Tesis, Universitas Diponegoro, Semarang, 2009, h. 52.

${ }^{6}$ Ibid.

7 Hamonangan Justinus Gultom dan Erna Susilawaty Sebayang, “Aspek Hukum Akta Pengakuan Hutang Dalam Perjanjian Kredit Konsumti”, Jurnal Ilmiah Skylandsea, Volume 2 No. 1 Februari 2018, h. 86 dan surat utang yang dibuat dihadapan Notaris di Indonesia dengan berkepala "Demi Keadilan Berdasarkan KeTuhanan Yang Maha Esa" mempunyai kekuatan yang sama dengan putusan hakim, dan apabila surat-surat seperti ini masalah pokoknya tidak dapat diselesaikan dengan jalan perdamaian, maka pelaksanaannya dilakukan. $^{8}$

Grosse akta pengakuan hutang adalah salinan dari suatu akta pengakuan hutang secara Notaril yang diberikan kepada yang berkepentingan yang tetap ada pada pejabat yang bersangkutan yang mempunyai kekuatan eksekutorial. ${ }^{9}$ Grosse akta pengakuan hutang yang dibuat oleh notaris mempunyai kekuatan hukum yang pasti sebagaimana Pasal 55 ayat (2) undang-undang tentang Jabatan Notaris menyatakan bahwa grosse akta pengakuan hutang yang dibuat dihadapan Notaris adalah salinan akta yang mempunyai kekuatan eksekutorial yang dapat dipergunakan oleh kreditur sebagai dasar hak untuk menagih piutangnya manakala pihak debitur lalai membayar hutangnya. Dengan kekuatan eksekutorial yang melekat pada grosse akta pengakuan hutang tersebut dapat memberikan kemudahan bagi bank untuk menghindari

\footnotetext{
${ }^{8}$ Ibid.

${ }^{9}$ Ibid.
} 
kesulitan-kesulitan dalam mengeksekusi barang yang dijaminkan. ${ }^{10}$

Namun praktiknya, saat debitur melakukan wanprestasi, pihak kreditur tidak langsung melaksanakan eksekusi jaminan akta pengakuan hutang yang telah dibuat dalam bentuk grosse. Pihak kreditur malah membuat Surat Pernyataan kerelaan pelepasan hak atas agunan yang dijaminkan tersebut dan ditandatangani oleh debitur. Padahal dengan adanya akta pengakuan hutang yang dibuat dihadapan Notaris inilah yang dapat diterbitkan salinannya oleh Notaris dan dinamakan dengan Grosse Akta Pengakuan Hutang. Grosse akta sendiri adalah merupakan suatu akta notaris yang memiliki sifat dan karakter khusus. ${ }^{11}$

Pihak kreditur atau Bank PT. Mandiri KCP Matang Geulumpang Dua masih menggunakan akta pengakuan hutang dalam perjanjian kredit dengan jaminan sertifikat hak milik. Hal itu disebabkan karena nilai uang yang dipinjam relatif kecil. Pada umumnnya penggunaan akta pengakuan hutang dibuat untuk pinjaman di bawah Rp.100.00.000,(seratus juta rupiah). Maka, apabila di atas

10 Shendy Vianni Rangian, "Pelaksanaan Eksekusi Grosse Akta Pengakuan Hutang Dalam Penyelesaian Sengketa Kredit Macet Perbankan", Jurnal Ilmiah Mahasiswa Universitas Surabaya, Volume 4 No.1, 2015, h. 3.

11 Victor M. Situmorang dan Cormentyna Sitanggang, Grosse Akta dalam Pembuktian dan Eksekusi, Rineka Cipta, Jakarta, 1998, h. 3
Rp.100.00.000,- (seratus juta rupiah), pihak kreditur atau Bank baru meminta untuk dibuatkan Akta Pembebanan Hak Tanggungan (APHT) ke Pejabat Pembuat Akta Tanah (PPAT) dan sertifikat tersebut didaftarkan ke Badan Pertanahan Nasional $(\mathrm{BPN}){ }^{12}$

\section{B. Rumusan Masalah}

Berdasarkan latar belakang masalah di atas, maka dapat dirumuskan permasalahan sebagai berikut:

1. Bagaimanakah kekuatan hukum eksekusi jaminan akta pengakuan hutang dalam perjanjian kredit?

2. Bagaimanakah akibat hukum terhadap debitur dalam akta pengakuan hutang apabila terjadi wanprestasi pada perjanjian kredit di PT. Bank Mandiri Kantor Cabang Pembantu Matang Geulumpang Dua Kabupaten Bireuen Aceh?

3. Bagaimanakah upaya hukum yang dilakukan kreditur dalam eksekusi jaminan akta pengakuan hutang pada perjanjian kredit di PT. Bank Mandiri Kantor Cabang Pembantu Matang Geulumpang Dua Kabupaten Bireuen Aceh?

${ }^{12}$ Rivi, Branch Manager PT. Bank Mandiri (Persero) Tbk, Capem Matang Glumpang Dua, Kabupaten Bireuen, Wawancara, Tanggal 23 Juli 2019. 
C. Metodologi

Jenis penelitian yang digunakan dalam penelitian ini adalah penelitian yuridis normatif. Penelitian normatif tersebut mengacu kepada norma-norma hukum yang terdapat dalam peraturan perundang-undangan dan putusan-putusan pengadilan serta norma-norma hukum yang ada dalam masyarakat.selain itu, dengan melihat sinkronisasi suatu aturan dengan aturan lainnya secara hierarki. ${ }^{13}$ Sumber data yang digunakan dalam penelitian ini bersumber dari data primer dan data sekunder. Data primer didapatkan melalui kegiatan penelitian lapangan yaitu berupa observasi dan wawancara terkait dengan permasalahan penelitian terhadap kekuatan hukum eksekusi jaminan akta pengakuan hutang dalam perjanjian kredit sehingga untuk membantu melancarkan penelitian ini dibutuhkan pendukung yaitu informan. Sedangkan data sekunder atau data kepustakaan yang terdiri dari bahan-bahan hukum. Bahan-bahan hukum tersebut terdiri dari bahan hukum primer yaitu peraturan perundang-undangan, yurisprudensi, traktat atau konvensi yang sudah diratifikasi, dan perjanjianperjanjian keperdataan para pihak; bahan hukum sekunder yaitu bahan yang

${ }^{13}$ Zainuddin Ali, Metode Penelitian Hukum, Raja Grafindo Persada, Jakarta, 1997, h. 38-39. memberikan penjelasan mengenai bahan hukum primer; dan bahan hukum tersier yaitu bahan yang memberikan petunjuk maupun penjelasan terhadap bahan hukum primer dan sekunder. ${ }^{14}$

Analisis data dalam penelitian ini menggunakan metode penelitian analisis data kualitatif. Metode analisis data kualitatif adalah analisis data yang tidak mempergunakan angka-angka tetapi berdasarkan atas peraturan perundangundangan, pandangan-pandangan informan sehingga dapat menjawab permasalahan dari peneltian ini. ${ }^{15}$ Setelah proses analisis dilakukan, ditarik kesimpulan dengan menggunakan metode berpikir deduktif yaitu cara berpikir yang dimulai dari halhal yang umum untuk selanjutnya menarik hal-hal yang khusus.

\section{Pembahasan}

I. Kekuatan Hukum Eksekusi Jaminan Akta Pengakuan Hutang Dalam Perjanjian Kredit

\section{a. Akta Pengakuan Hutang dalam Perjanjian Kredit}

Perjanjian kredit menurut hukum perdata diidentikkan dengan perjanjian pinjam-meminjam sebagaimana diatur dalam pada Pasal 1754-1769 KUHPerdata Perjanjian kredit merupakan perjanjian

\footnotetext{
${ }^{14}$ Bahder Johan Nasution, Metode Penelitian Ilmu Hukum, Mandar Maju, Bandung, 2008, h. 86.

${ }^{15}$ Burhan Bungin, Analisis Data Penelitian Kualitatif, Pemahaman Filosofis Dan Metodologis Kearah Penguasaan Modal Aplikasi, Raja Grafindo Persada, Jakarta, 2004, h. 53
} 
pendahuluan atau voorovereenkomst dalam hal ini tentunya yang dimaksud adalah perjanjian pendahuluan dari penyerahan uang $^{16}$ yang bersifat konsensuil. Dalam prakteknya, setelah perjanjian kredit biasanya akan diikuti dengan dibuatnya akta pengakuan hutang sebagai bentuk telah direalisasikannya kredit, yaitu penyerahan pinjaman (uang) secara riil oleh bank kepada debitur macet yang dibuat secara notariil karena akta pengakuan hutang dapat dimintakan grosse aktanya. Grosse akta pengakuan hutang yang dibuat oleh notaris mempunyai kekuatan hukum yang pasti sebagaimana Pasal 55 ayat (2) UndangUndang Nomor 2 Tahun 2014 tentang Jabatan Notaris menyatakan bahwa "grosse akta pengakuan hutang yang dibuat dihadapan Notaris adalah salinan akta yang mempunyai kekuatan eksekutorial yang dapat dipergunakan oleh kreditur sebagai dasar hak untuk menagih piutangnya manakala pihak debitur lalai membayar hutangnya." Dengan kekuatan eksekutorial yang melekat pada grosse akta pengakuan hutang tersebut dapat memberikan kemudahan bagi bank untuk

16 Mariam Darus Badrulzaman, Perjanjian Kredit Bank, Citra Aditya, Bandung, 1991, h. 26 menghindari kesulitan-kesulitan dalam mengeksekusi barang yang dijaminkan. ${ }^{17}$

Akta pengakuan hutang merupakan suatu pengakuan atas terjadinya suatu transaksi peminjaman sejumlah dana/uang dan bukti dari peminjaman tersebut yang dituangkan dalam bentuk perjanjian pengakuan hutang yang memiliki sifat eksekutorial akta. Pengakuan hutang dalam transaksi ini merupakan dokumen penting dan berguna sebagai bukti pernah atau telah terjadi suatu hubungan hukum antara kreditur dan debitur, dan hubungan hukum ini merupakan suatu peristiwa yang memiliki aspek hak dan kewajiban sehingga menimbulkan prestasi dan sanksi bagi kedua belah pihak. Kegunaan dari akta pengakuan hutang adalah sebagai kekuatan bukti bagi pihak bank apabila debitur melakukan wanprestasi yang dapat merugikan bank. ${ }^{18}$

Penggunaan grosse akta pengakuan utang dalam melakukan eksekusi jaminan kredit mempunyai keuntungan bagi pihak kreditur bisa menghemat waktu, hemat biaya dan menimbulkan kepastian hukum. Disamping itu proses eksekusi haruslah memenuhi tata cara dan syarat-syarat serta

\footnotetext{
${ }^{17}$ Shendy Vianni Rangian, "Pelaksanaan Eksekusi Grosse Akta Pengakuan Hutang dalam Penyelesaian Sengketa Kredit Macet Perbankan", Jurnal Ilmiah Mahasiswa Universitas Surabaya Voume 4, Nomor 1, 2015, h. 2.

18 Hamonangan Justinus Gultom dan Erna Susilawaty Sebayang, op.cit., h. 84.
} 
tahapan-tahapan yaitu peringatan (aanmaning), penetapan dan berita acara eksekusi. Penyalahgunaan isi grosse akta dengan adanya pencampuradukan isi antara grosse akta hipotek dengan grosse akta pengakuan utang, kekeliruan cara penerbitan dokumen akta kuasa memasang hipotek, dan kendala executorial verkoop atas grosse akta ialah mengenai soal perselisihan jumlah utang yang harus dibayar debitur. ${ }^{19}$

Grosse akta pengakuan hutang bersifat accessoire, artinya grosse akta tersebut selalu mengikuti perjanjian pokoknya. Apabila perjanjian berakhir maka akta pengakuan hutang juga berakhir. Oleh karena itu, pembuatan akta pengakuan hutang dalam perjanjian kredit adalah sebagai perjanjian tambahan dan perjanjian kredit merupakan perjanjian pokoknya. $^{20}$

\section{b. Pelaksanaan Eksekusi Jaminan Akta Pengakuan Hutang dalam Perjanjian Kredit}

Istilah eksekusi dalam literatur Hukum Acara Perdata adalah "pelaksanaan putusan”. Eksekusi sebagai tindakan hukum yang dilakukan oleh pengadilan kepada pihak yang kalah dalam

\footnotetext{
19 Ibid.

${ }^{20}$ Riny Dwiyanti Manaroinsong, Kedudukan Hukum Surat Kuasa Menjual Terhadap Objek Jaminan Yang Dibebani Dengan Hak Tanggungan, Tesis, Fakultas Hukum, Program Kenotariatan, Universitas Hasanuddin. 2012., h. 4.
}

suatu perkara merupakan aturan dan tata cara lanjutan dari proses pemeriksaan perkara. Eksekusi ini dapat pula dapat diartikan "menjalankan putusan" pengadilan, yang melaksanakan secara paksa putusan pengadilan dengan bantuan kekuatan umum apabila pihak yang kalah tidak mau menjalankannya secara sukarela, eksekusi dapat dilaksanakan apabila telah memperoleh kekuatan hukum tetap. $^{21}$

Adapun tahap-tahap pelaksanaan eksekusi tersebut, sebagai berikut: ${ }^{22}$

1) Perbuatan hukum berupa kesepakatan dan kemufakatan diantara pihak-pihak yang berkepentingan itu, mereka harus menuangkannya dalam sebuah akta notaris, yang memuat isi perjanjian, hak-hak dan kewajiban, tuntutan dan prestasi dari masing-masing pihak, yang karenanya menurut hukum, perjanjian dan kesepakatan diantara pihak-pihak yang termuat didalam akta itu kekuatannya sama dengan undang-undang sehingga bersifat memaksa dan mengikat pihak-pihak untuk melaksanakannya.

2) Masing-masing pihak pada akta, yang mempunyai hak tagih, yang mempunyai hak untuk menuntut prestasi dari "pihak lawan" (tegen

21 Saraswati Jaya, Perlindungan Hukum Terhadap Bank Sebagai Kreditor Pemegang Hak Tanggungan Dalam Penangguhan Eksekusi Jaminan Berkaitan Dengan Undang-Undang Nomor 37 Tahun 2004 Tentang Kepailitan, Tesis,Fakultas Hukum, Program, Magister Kenotariatan, Universitas Sumatera Utara, 2010, h. 31.

${ }^{22}$ M.Yahya Harahap, SH, Ruang Lingkup Permasalahan Eksekusi Bidang Perdata, Sinar Grafika,

Jakarta, 2006, h. 131-132. 
pertij) didalam akta yang bersangkutan, diperbolehkan atau berhak untuk meminta dan memperoleh GROSSE dari akta tersebut, yang tidak lain itu adalah salinan/turunan yang sama bunyinya/isinya dengan minuta akta dimaksud. Karena itu, notaris yang memuat akta yang bersangkutan, berkewajiban dan secara hukum terikat untuk memberikan salinan dan/atau GROSSE dari akta itu, kepada pihak yang berkepentingan langsung, atau para penerima hak dari padanya atau para ahli warisnya.

3) Pihak pemegang GROSSE dari akta notaris yang bertitel eksekutorial tersebut dengan memakai judul "DEMI

KEADILAN BERDASARKAN KETUHANAN YANG MAHA ESA", dapat, boleh dan berhak untuk meminta "fiat eksekusi" kepada/melalui Ketua Pengadilan Negeri (menurut sistem hukum, tidak diperlukan fiat eksekusi).

4) Ketua Pengadilan, terikat dan berkewajiban untuk memenuhi permintaan pihak yang berkepentingan, dengan dasar GROSSE akta notaris itu, sehingga eksekusi tersebut dapat terlaksana secara efektif; kesemuannya itu telah dijamin oleh hukum dan perundangundangan yang berlaku, sekaligus diterima dan diakui oleh serta sesuai pula dengan kesadaran hukum masyarakat, atau dengan kata lain, tidak akan ada alasan yang berdasar, bagi siapapun juga untuk menundanunda dan menghalang-halangi apalagi untuk menolak pelaksanaan eksekusi berdasarkan GROSSE dari akta notaris, kecuali "hasad" asal dasar pangkal penyebabnya.

5) Juru sita dan demikian juga juru lelang atau pejabat siapapun, yang diberi wewenang serta kekuasaan untuk melaksanakannya, terikat dan berkewajiban untuk menjalankan tugas, kewajiban serta bertanggung jawab penuh dengan segala konsekwensi dan resikonya.

6) Ketua Mahkamah Agung sebagai lembaga tertinggi yudikatip, berdasarkan peraturan perundangundangan, paling tidak diatur dalam 7 peraturan perundang-undangan yang hingga saat ini masih tetap berlaku, kewajiban dan ketanggungjawab untuk melakukan pengawasan terhadap para ketua Pengadilan, para hakim Pengadilan dan pelaksanaan eksekusi itu sendiri. Pengambilan dan penerimaan dari hasil eksekusi itu sendiri, tidak boleh melebihi dari porsi dan hak bagian pihak-pihak yang berkepentingan sebagaimana telah ditentukan didalam GROSSE dari akta notaris yang bersangkutan.

\section{c. Kekuatan Hukum Eksekusi}

Jaminan Akta Pengakuan Hutang dalam Perjanjian Kredit

Akta pengakuan hutang tersebut dapat dijadikan sebagai bukti penuntutan suatu hak karena dianggap sebagai tanda alas hak yang asli, asal dari akta itu cukup jelas isi alas hak tersebut. ${ }^{23}$ Dalam kaitannya dengan perjanjian kredit bahwa dalam praktak pemberian kredit Grosse akta tersebut merupakan alat bukti adanya utang, adapun alasan dibuatnya Grosse akta pengakuan utang adalah sebagai berikut: $^{24}$

1) Perjanjian kredit tidak mempunyai kekuatan eksekutorial sehingga jika

${ }^{23}$ Pasal 1891 KUHPerdata

24 Febby M. Sukatendel, Panduan Bantuan Hukum di Indonesia; pedoman anda memahami dan menyelesaikan masalah hukum (Kredit dan Masalah Keuangan), YLBHI, Jakarta, 2009, h. 139. 
debitur melakukan wanprestasi maka kreditur tidak dapat melakukan eksekusi langsung terhadap jaminan yang ada tetapi harus melakukan gugatan melalui Pengadilan Negeri terlebih dahulu kepada debitur.

2) Akta pengakuan utang merupakan perjanjian sepihak, di dalamnya hanya dapat memuat suatu kewajiban untuk membayar utang sejumlah uang tertentu. Akta pengakuan utang yang dibuat di hadapan Notaris berdasarkan Pasal 224 HIR/258 RGB memiliki kekuatan hukum yang sama seperti keputusan hakim yang bersifat tetap atau dengan kata lain dapat diartikan bahwa akta pengakuan hutang memiliki kekuatan eksekutorial.

3) Mempercepat proses eksekusi tanpa memerlukan gugatan terlebih dahulu kepada debitur.

Karena grosse akta itu mempunyai kekuatan pembuktian yang sama dengan akta aslinya, maka grosse akta itu juga merupakan bukti yang sempurna bagi para pihak dalam akta itu dan para ahli warisnya dan sekalian orang yang mendapat hak daripadanya, sebagaimana diatur dalam Pasal 165 HIR dan Pasal 1870 KUHPerdata. Sebagaimana telah diketahui bahwa setiap akta otentik mempunyai kekuatan pembuktian, yaitu kekuatan pembuktian lahir, kekuatan pembuktian formil dan kekuatan pembuktian materiil, maka grosse akta pun sesuai dengan Pasal 1889 KUHPerdata tersebut di atas memilik kekuatan pembuktian tersebut. ${ }^{25}$

\footnotetext{
${ }^{25}$ Ibid., h. 141.
}

Pihak kreditur (bank) berharap pelaksanaan eksekusi akta pengakuan utang tidak perlu lagi melalui proses gugatan yang bisa menyita waktu lama dan memakan biaya yang besar, namun akibat dari wanprestasi tersebut kreditur tidak langsung melakukan eksekusi peralihan hak atas jaminan yang telah diberikan debitur. Kreditur akan melakukan upayaupaya pendekatan secara persuasif untuk menghindari eksekusi peralihan hak sebagaimana termuat dalam akta pengakuan utang. Dikarenakan upaya persuasif tidak membuahkan hasil, maka upaya peralihan hak akan dilakukan oleh kreditur sebagai upaya terakhir. Untuk upaya terakhir ini kreditur masih meminta pernyataan pelepasan hak dari debitur secara suka rela yang di tuang dalam sebuah surat pernyataan. ${ }^{26}$

Namun, apabila irah-irah "Demi Keadilan Berdasarkan Ketuhanan Yang Maha Esa" tak dicantumkan, akibatnya akta pengakuan utang tersebut dianggap tidak mempunyai kekuatan hukum tetap sebagaimana putusan yang dikeluarkan oleh pengadilan yang telah mempunyai kekuatan hukum tetap dan pembuatan akta pengakuan utang tersebut dianggap tidak mempunyai kekuatan eksekutorial.

${ }^{26}$ Rivi Kurniawan, Branch Manager PT. Bank Mandiri (Persero) Tbk, Capem Matang Glumpang Dua, Kabupaten Bireuen, Wawancara, Tanggal 23 Juli 2019. 
II. Akibat Hukum Terhadap Debitur Dalam Akta Pengakuan Hutang Apabila Terjadi Wanprestasi pada Perjanjian Kredit di PT. Bank Mandiri Kantor Cabang Pembantu Matang Geulumpang Dua Kabupaten Bireuen Aceh

a. Tinjauan Yuridis tentang Kreditur dan Debitur

Berdasarkan Undang-Undang

Nomor 37 Tahun 2004 tentang Kepailitan dan Penundaan Kewajiban Pembayaran Utang adapun pengertian kreditur adalah adalah orang yang mempunyai piutang karena perjanjian atau Undang-Undang yang dapat ditagih di muka pengadilan. ${ }^{27}$ Namun dalam penjelasan Pasal 2 ayat (1) Undang-Undang Nomor 37 Tahun 2004 memberikan defenisi yang dimaksud dengan kreditur dalam ayat ini adalah baik kreditur konkuren, kreditur separatis maupun kreditur preferen. Khusus mengenai kreditur separatis dan kreditur preferen, mereka dapat mengajukan permohonan pernyataan pailit tanpa kehilangan hak agunan atas kebendaan yang mereka miliki terhadap harta debitur dan haknya untuk didahulukan. Sedangkan Debitur adalah orang yang mempunyai utang karena perjanjian atau undangundang yang pelunasannya dapat ditagih di muka pengadilan. ${ }^{28}$

${ }^{27}$ Pasal 1 angka 2 Undang-Undang No. 37 Tahun 2004 tentang Kepailitan dan Penundaan Kewajiban Pembayaran Utang

${ }^{28}$ Ibid.
Selain itu adapun pengertian lain kreditur dan debitur yaitu Kreditur adalah pihak bank atau lembaga pembiayaan lainnya yang mempunyai piutang karena perjanjian atau undang-undang. ${ }^{29}$ Debitur adalah orang atau badan usaha yang memilki hutang kepada bank atau lembaga pembiayaan lainnya karena perjanjian atau undang-undang. ${ }^{30}$

\section{b. Pengertian Wanprestasi}

Wanprestasi adalah tidak memenuhi atau lalai melaksanakan kewajiban sebagaimana yang ditentukan dalam perjanjian yang dibuat antara kreditur dengan debitur. ${ }^{31}$ Wanprestasi atau tidak dipenuhinnya janji dapat terjadi baik karena disengaja maupun tidak disengaja. ${ }^{32}$ Seorang debitur dikatakan lalai, apabila ia tidak memenuhi kewajibannya atau terlambat memenuhinya tetapi tidak seperti yang telah diperjanjikan. ${ }^{33}$ Wanprestasi terjadi apabila salah satu pihak dalam perjanjian tidak melaksanakan atau lalai melaksanakan prestasi (kewajiban) yang

${ }^{29}$ Riduan Tobink dan Bill Nikholaus, 2003. “Kamus Istilah Perbankan”, Atalya Rileni Sudeco, Jakarta. h.118.

${ }^{30}$ Ibid.

31 Salim HS, Pengantar Hukum Perdata Tertulis (BW), Jakarta, 2008), h.180.

${ }^{32}$ Ahmadi Miru, Hukum Kontrak dan Perancangan Kontrak, Jakarta:Rajawali Pers, 2007, ,h. 74.

${ }^{33}$ Subekti, Kitab Undang-Undang Hukum Perdata, Jakarta, Arga Printing, 2007, h.146. 
menjadi objek perikatan antara mereka dalam kontrak. ${ }^{34}$

\section{c. Akibat Hukum terhadap Debitur dalam Akta Pengakuan Hutang Apabila Terjadi Wanprestasi pada Perjanjian Kredit}

Apabila debitur melakukan

wanprestasi, pihak bank sebagai kreditur untuk pertama kali akan melakukan upaya persuasif melalui teguran baik secara lisan atau melalui surat, dan apabila upaya yang pertama gagal, maka bank akan memanggil debitur untuk datang ke bank membicarakan masalah yang di hadapi debitur mengenai wanprestasinya. Setelah itu antara bank dengan debitur mencari jalan keluar dari permasalahan yang di hadapi debitur, baik dengan cara menambah jangka waktu fasilitas dengan memberi keringanan atas kewajibannya atau dibatalkannya perjanjian dengan dibuatnya perjanjian baru, dengan pertimbangan melihat kemampuan atau niat baik debitur. Selanjutnya upaya hukum (eksekusi) yang akan ditempuh oleh bank adalah sebagai pilihan akhir dan mekanismenya sesuai dengan undangundang yang berlaku. ${ }^{35}$ Eksekusi tersebut dapat dilakukan dengan cara menjual objek jaminan Hak Tanggungan melalui

\footnotetext{
34 Ricardo Simanjuntak, Teknik Perancangan Perjanjian Bisnis, Jakarta, Kontan Publishing: 2011, h. 217

${ }^{35}$ Rivi Kurniawan, Branch Manager PT. Bank Mandiri (Persero) Tbk, Capem Matang Glumpang Dua, Kabupaten Bireuen, Wawancara, Tanggal 23 Juli 2019.
}

lelang oleh badan lelang atau dijual di bawah tangan atas dasar kesepakatan antara kreditur dan debitur yang tujuannya untuk memperoleh harga tertinggi sebagai solusi terbaik bagi para pihak. ${ }^{36}$

Penyelesaian kredit macet melalui Pengadilan Negeri dapat ditempuh dengan dua cara, yaitu dengan cara memohonkan penetapan sita eksekusi (executorial beslag) terhadap Grosse Akta Pengakuan Hutang ataupun terhadap Grosse Akta Hak Tanggungan kepda Ketua Pengadilan Negeri atau dengan cara mengajukan gugatan biasa disertai dengan permohonan sita jaminan terhadap barang-barang jaminan kredit yang telah macet tersebut, dimana sita jaminan akan berubah kedudukannya menjadi sita eksekusi (executorial beslag) jika gugatan penggugat (dalam hal ini kreditur)dikabulkan oleh hakim. ${ }^{37}$

Pihak debitur dalam kasus penelitian ini telah melakukan wanprestasi dan memilih untuk melakukan pembatalan terhadap perjanjian pokok disertai dengan pelepasan hak atas agunan yang telah

${ }^{36}$ Salawati Suyitno, "Analisis Yuridis Terhadap Eksekusi Benda Jaminan yang Dibebani Hak Tanggungan Pada Debitur Pailit", Tesis, Universitas Sumatera Utara, Medan, 2017, h. 3-4. Lihat: Rachman Marwali, Pembatalan APHT Akibat Tidak Berwenangnya Debitur Pemberi Hak Tanggungan, Bumi Aksara, Jakarta, 2012, h. 9.

37 Ermalisa Tarigan, Eksekusi barang Jaminan oleh Bank dalam Penyelesaian Kredit Macet (Studi Kasus Pada Bank “D” di Medan), Tesis, Program Kenotariatan, Universitas Sumatera Utara, h. 16. 
dijaminkan ke bank (kreditur). Alasannya dikarenakan debitur tidak mampu memenuhi kewajibannya sebagaimana yang telah diperjanjikan. Dalam suatu perjanjian yang telah disepakati oleh para pihak yang terkait, akan melahirkan suatu hak dan kewajiban dari para pihak tersebut. Kewajiban dari suatu hak akan menjadi hak bagi pihak yang lainnya. Kewajiban yang timbul dalam suatu perjanjian harus dipenuhi oleh pihak yang bersangkutan, apabila kewajiban itu tidak terlaksana sesuai dengan isi perjanjian, maka dapat dikatakan telah melakukan wanprestasi. Dalam hal tenggang waktu pelaksanaan pemenuhan prestasi itu ditentukan, maka menurut ketentuan Pasal 1238 KUH Perdata, debitur dianggap lalai dengan lewatnya waktu sesuai dengan apa yang telah diperjanjikan sebagaimana termuat dalam Akta Pengakuan Hutang. Adapun ketentuan Pasal 1238 KUH Perdata sebagai berikut: "Si berutang adalah lalai, apabila ia dengan surat perintah atau dengan sebuah akta sejenis itu telah dinyatakan lalai, atau demi perikatannya sendiri, ialah jika ini menetapkan, bahwa si berutang harus dianggap lalai dengan lewatnya waktu yang ditentukan". ${ }^{38}$

\section{Upaya Hukum Yang Dilakukan} Kreditur dalam Eksekusi Jaminan Perdata.

\section{Akta Pengakuan Hutang pada Perjanjian Kredit di Desa Matang Geulumpang Dua}

a. Tinjauan Yuridis Akta Pengakuan Hutang

Akta pengakuan hutang merupakan suatu akta yang dibuat dalam bentuk notariil, dimana akta tersebut hanya memuat pengakuan hutang seseorang, berikut dengan jumlah hutang, suku bunga, jangka waktu, tempat pembayaran, hal-hal yang dapat menyebabkan hutang dapat ditagih atau dibayar seketika (opeisbaarheid), jaminan dan tidak disertai dengan persyaratan-persyaratan lain terlebih apabila persyaratan tersebut berbentuk perjanjian. ${ }^{39}$ Pengakuan hutang secara umum didefinisikan juga sebagai "suatu pengakuan atas terjadinya suatu transaksi peminjaman sejumlah dana/uang." Pengakuan hutang dalam transaksi kredit ini merupakan dokumen penting, yang berguna sebagai bukti pernah atau telah terjadi suatu hubungan hukum antara kreditur dengan debitur, hubungan hukum ini merupakan aspek hak dan kewajiban, sehingga menimbulkan prestasi dan sanksi terhadap kedua belah pihak.Hasil dari transaksi tersebut dituangkan dalam bentuk akta yang dinamakan Akta Pengakuan hutang, akta

${ }^{39}$ Didi Santoso, "Tanggung Jawab Notaris Dalam Pembuatan Akta Yang Memuat Dua Perbuatan Hukum (Analisis Putusan Mhkamah Agung Nomor 1440.K/Pdt/1996)." Tesis, Universitas Diponegoro, Semarang, 2009, h. 52. 
ini dapat dibuat di bawah tangan atau dengan akta autentik dihadapan Notaris, dan dilengkapi dengan Grosse akta pengakuan hutang. ${ }^{40}$

\section{b. Tinjauan Yuridis Perjanjian Kredit}

\section{Pengertian Perjanjian Kredit}

Perjanjian kredit merupakan perikatan dua belah pihak atau lebih dimana perjanjian kredit menggunakan uang sebagai objek dari perjanjian. Jadi perjanjian kredit itu merupakan perjanjian pinjam meminjam uang antara bank sebagai kreditur dan nasabah sebagai debitur dimana dalam perjanjian ini bank sebagai pemberi kredit percaya terhadap nasabahnya dalam jangka waktu tertentu sebagaimana telah disepakati akan dikembalikan atau dibayar lunas. Tenggang waktu antara pemberian dan penerimaan kembali prestasi ini merupakan sesuatu yang keharusan yang dapat berjalan beberapa bulan tetapi dapat juga berjalan hingga beberapa tahun. ${ }^{41}$

Perjanjian kredit (credit/loan agreement) merupakan salah satu perjanjian yang dilakukan antara bank dengan pihak ketiga, yang dalam hal ini adalah nasabahnya. Perjanjian kredit

${ }^{40}$ Hamonangan Justinus Gultom dan Erna Susilawaty Sebayang, "Aspek Hukum Akta Pengakuan Hutang Dalam Perjanjian Kredit Konsumtif', Jurnal Ilmiah Skylandsea, ISSN: 2614-5154. Volume 2 No. 1 Februari 2018, h.

41 Hamonangan Justinus Gultom dan Erna Susilawaty Sebayang, op.cit., h. 85. sebenarnya dapat dipersamakan dengan perjanjian utang-piutang. Perbedaannya, istilah perjanjian kredit umumnya dipakai oleh bank sebagai kreditur, sedangkan perjanjian utang-piutang umumnya dipakai oleh masyarakat dan tidak terkait dengan bank. ${ }^{42}$

\section{Fungsi Perjanjian Kredit}

Perjanjian kredit ini perlu mendapat perhatian yang khusus, baik oleh pihak bank sebagai kreditur maupun oleh nasabah sebagai debitur karena perjanjian kredit mempunyai fungsi yang sangat penting dalam pemberian, pengelolaan, ataupun penetalaksanaan kredit itu sendiri. Perjanjian kredit mempunyai beberapa fungsi, di antaranya: ${ }^{43}$

a) Perjanjian kredit sebagai perjanjian pokok. Artinya, perjanjian kredit merupakan sesuatu yang menentukan batal atau tidak batalnya perjanjian lain yang mengikutinya, misalnya: perjanjian pengikat jaminan.

b) Perjanjian kredit sebagai alat bukti mengenai batasanbatasan hak dan kewajiban di antara kreditur dan debitur.

c) Perjanjian kredit sebagai alat untuk melakukan monitoring kredit

\section{Berakhirnya Perjanjian Kredit}

Berakhirnya perjanjian kredit saat Perjanjian berakhir apabila terjadi hapusnya perikatan, Secara keseluruhan,

${ }^{42}$ Ibid.

43 R Subekti, Aneka Perjanjian, Bandung, Citra Aditya Bakti, 1995, h. 125 
Pasal 1381 KUHPerdata menyebutkan sepuluh cara hapusnya suatu perikatan, yaitu:

a.) Pembayaran

b.) Penawaran pembayaran tunai diikuti oleh penyimpanan

c.) Pembaharuan utang

d.) Kompensasi atau perjumpaan utang

e.) Percampuran utang

f.) Pembebasan Utang

g.) Hapusnya Barang yang dimaksudkan dalam perjanjian

h.) Batal atau pembatalan

i.) Berlakunya suatu syarat batal

j.) Lewat Waktu

\section{Isi dalam Perjanjian Kredit}

Adapaun isi dari Perjanjian Kredit adalah sebagai berikut:

a) Pasal yang mengatur jumlah kredit;

b) Pasal yang mengatur jangka waktu kredit;

c) Pasal yang mengatur bunga kredit, denda, biaya-biaya lainnya yang timbul dari pemberian kredit.

d) Pasal yang mengatur tentang syarat-syarat;

e) penarikan dan pencairan kredit;

f) Pasal yang mengatur penggunaan kredit;

g) Pasal yang mengatur pengembalian kredit;

h) Pasal yang mengatur jaminan kredit;

i) Pasal yang mengatur kelalaian debitur atau wanprestasi;

j) Pasal yang mengatur hal-hal yang harus dilakukan debitur;

k) Pasal yang mengatur pembatasan terhadap tindakan;

1) Pasal yang mengatur tentang asuransi barang jaminan;

m) Pasal yang mengatur pernyataan jaminan; n) Pasal yang mengatur perselisihan dan penyelesaian sengketa;

o) Pasal yang mengatur keadaan yang memaksa;

p) Pasal yang mengatur pemberitahuan dan komunikasi;

q) Pasal yang mengatur pengalihan dan perubahan.

c. Kronologis Terjadinya Eksekusi Jaminan Pengakuan Hutang dalam Perjanjian Kredit

PT. Bank Mandiri dan Tuan X telah memenuhi kriteria cakap dan sepakat, sebagai subyek hukum recht persoon dan natuur persoon, maksudnya bahwa para pihak yang membuat perjanjian, apabila orang-perorangan harus sudah dewasa, sehat akal-fikir, dan tidak di bawah perwalian/pengampuan, dan apabila yang melakukan perjanjian adalah suatu badan hukum atau organisasi, maka harus orang yang mempunyai kewenangan atau kompeten untuk melakukan hubungan hukum dengan pihak lain. Apabila syarat ini tidak terpenuhi, maka status perjanjian tersebut dapat dibatalkan. Subyek hukum badan hukum (recht persoon) merupakan badan-badan perkumpulan atau organisasiorganisasi yakni orang-orang yang diciptakan oleh hukum yang diberikan kewenangan untuk bertindak atas nama badan hukum, dalam hal ini adalah PT. Bank Mandiri sebagai badan hukum dan sebagai subyek hukum dapat bertindak hukum (melakukan perbuatan hukum) seperti manusia, dengan demikian PT. 
Bank Mandiri sebagai pembawa hak dan kewajiban serta tidak berjiwa, dapat melakukan persetujuan-persetujuan atau perjanjian-perjanjian dan memiliki kekayaan yang terlepas dari kekayaan pegawai atau karyawan-karyawannya, oleh karena itu badan hukum dapat bertindak dengan perantara pengurus-pengurusnya, sedangkan Tuan X sebagai subjek hukum manusia (natuur persoon) merupakan orang perorangan, yang secara kodratnya telah menjadi subjek hukum sejak ia masih dalam kandungan apabila ada kepentingan yang mengehendakinya. Beda badan hukum dengan manusia, kalau badan hukum tidak dapat melakukan perkawinan, tidak dapat diberi hukuman penjara, akan tetapi apabila badan hukum melanggar undang-undang atau ketentuan-ketentuan yang telah ada, maka kemungkinan sanksinya adalah dapat dibubarkan atau dicabut izinnya, sedangkan untuk manusia apabila melakukan perbuatan melawan hukum bisa dipidanakan baik dalam bentuk pidana penjara badan atau kurungan atau bisa juga dikenakan sanksi perdata. $^{44}$

Perbuatan hukum yang terjadi antara subjek hukum tersebut diatas dikarenakan adanya obyek yang diperjanjikan. Dalam hal ini obyek yang diperjanjikan adalah

${ }^{44}$ Syukri, Notaris/PPAT, Kabupaten Bireuen, Wawancara, Tanggal 22 Juli 2019. kredit sejumlah Rp. 90.000.000,(sembilan puluh juta rupiah) dengan jaminan agunan berupa sebidang tanah perumahan teratur dan sebidang tanah sawah. Sehingga PT. Bank Mandiri Persero Tbk Matang Glumpang Dua Cabang Banda Aceh yang diwakili oleh branch managernya selaku kreditur dan Tuan X selaku debitur membuat perjanjian kredit. Selanjutnya kedua pihak sepakat untuk mengikatkan diri dan melaksanakan perjanjian dalam bentuk akta pengakuan utang. Debitur atas kredit yang diberikan kepadanya adalah tidak semata-mata melunasi utangnya, tetapi juga disertai dengan bunga sesuai dengan perjanjian yang telah disepakati sebelumnya. Perjanjian kredit merupakan perjanjian pokok. Materi dari perjanjian kredit (akad kredit) dipersiapkan oleh pihak kreditur atas kesepakatan bersama antara kreditur dengan calon debitur. Kreditur (bank) akan mengirim ahli hukumnya untuk mendampingi account officer/wira kredit dalam membahas berbagai ketentuan yang harus dimuat dalam perjanjian kredit. Ketentuan-ketentuan tersebut diambil dari hasil analisa kredit yang dituangkan dalam Surat Persetujuan Kredit (SPK) termasuk revisi atau perubahan yang dipersyaratkan oleh komite kredit maupun direksi bank. Selanjutnya kedua pihak sepakat untuk mengikatkan diri dan melaksanakan 
perjanjian dalam bentuk akta pengakuan utang. Akta pengakuan utang wajib dibuat karena debitur memohon pencairan dana kredit sejumlah Rp. 50.000.000,- (lima puluh juta rupiah) ke atas, dan di bawah Rp. 100.000.000,- (seratus juta rupiah). Dalam hal ini dana yang diminta oleh debitur sejumlah Rp. 90.000.000,(sembilan puluh juta rupiah), dan pihak kreditur menyetujuinya setelah debitur memenuhi syarat-syarat yang diminta oleh kreditur. Setelah kreditur dan debitur sepakat melakukan akad kredit, selanjutnya dibuat akta notariil yaitu Akta Pengakuan Utang yang ditandatangani di hadapan notaris, disamping biaya murah, akta pengakuan utang ini lebih cepat pembuatannya. ${ }^{45}$

Setelah dana kredit cair, beberapa bulan kemudian pihak debitur tidak dapat melanjutkan angsuran kredit. Debitur hanya membayar sebagian angsuran kredit. Akibat dari wanprestasi yang dilakukan oleh debitur, pihak kreditur telah membuat surat pernyataan kerelaan pelepasan hak atas agunan yang dijaminkan debitur tersebut dan meminta debitur untuk menandatangani surat tersebut. ${ }^{46}$

\section{d. Upaya Hukum yang Dilakukan Kreditur dalam Eksekusi Jaminan}

${ }^{45}$ Rivi Kurniawan, Branch Manager PT. Bank Mandiri (Persero) Tbk, Capem Matang Glumpang Dua, Kabupaten Bireuen, Wawancara, Tanggal 23 Juli 2019.

${ }^{46}$ Ibid.

\section{Akta Pengakuan Hutang pada Perjanjian Kredit Di Desa Matang Geulumpang Dua \\ Berdasarkan penelitian ini,} pelaksanaan eksekusi grosse akta tidak langsung dilakukan. Saat debitur telah melakukan wanprestasi dalam perjanjian kredit, pihak kreditur atau Bank tidak meminta penetapan dari Pengadilan Negeri untuk melangsungkan eksekusi jaminan akta pengakuan hutang secara lelang. Lazimnya prosedur normal yang dilakukan oleh Bank apabila terjadi kredit macet, Bank melakukan penyelamatan kredit atau penyelesaian kredit. Dalam penelitian ini Pihak Kreditur atau Bank melakukan penyelamatan kredit dengan membuat surat pernyataan kerelaan pelepasan hak atas agunan yang dijaminkan debitur tersebut dan meminta debitur untuk menandatangani surat tersebut.

Pihak kreditur (bank) berharap pelaksanaan eksekusi akta pengakuan utang tidak perlu lagi melalui proses gugatan yang bisa menyita waktu lama dan memakan biaya yang besar, namun akibat dari wanprestasi tersebut kreditur tidak langsung melakukan eksekusi peralihan hak atas jaminan yang telah diberikan debitur. Kreditur akan melakukan upayaupaya pendekatan secara persuasif untuk menghindari eksekusi peralihan hak sebagaimana termuat dalam akta pengakuan utang. Dikarenakan upaya 
persuasif tidak membuahkan hasil, maka upaya peralihan hak akan dilakukan oleh kreditur sebagai upaya terakhir. Untuk upaya terakhir ini kreditur masih meminta pernyataan pelepasan hak dari debitur secara suka rela yang di tuang dalam sebuah surat pernyataan. ${ }^{47}$

Surat pernyataan penyerahan secara suka rela atas objek jaminan berupa tanah berdasarkan akta pengakuan hutang telah ditandatangani oleh pemilik hak (debitur) yang melakukan wanprestasi karena tidak mampu lagi memenuhi kewajibannya, akan tetapi pihak kreditur belum juga melakukan eksekusi terhadap tanah tersebut, pihak kreditur masih mengulurngulur waktu untuk mengambil pelunasan utang debitur. ${ }^{48}$

Biarpun debitur telah menandatangani surat pernyataan penyerahan jaminan secara suka rela, pihak kreditur masih menghindari pelaksanaan eksekusi, karena utang debitur yang tersisa sebagian menurut perhitungan utang pokok menjadi alasan ditundanya eksekusi atas objek jaminan akta pengakuan hutang oleh pihak kreditur. Oleh sebab itu, pihak kreditur memberikan kebijakan kepada debitur untuk melunasi

\footnotetext{
${ }^{47}$ Rivi Kurniawan, Branch Manager PT. Bank Mandiri (Persero) Tbk, Capem Matang Glumpang Dua, Kabupaten Bireuen, Wawancara, Tanggal 23 Juli 2019.

${ }^{48}$ Tuan X, debitur PT. Bank Mandiri (Persero) Tbk Matang Glumpang Dua, Kabupaten Bireuen, Wawancara, Tanggal 30 Juli 2019.
}

utangnya dengan cara menambah jangka waktu pelunasan dengan cicilan yang lebih rendah. ${ }^{49}$

Seharusnya dengan adanya akta pengakuan hutang yang telah dibuat sebelumnya, pihak kreditur atau Bank dapat langsung melakukan eksekusi terhadap objek jaminan akta pengakuan hutang tersebut, sehingga tidak perlu lagi membuat surat pernyataan penyerahan secara sukarela atas jaminan akta pengakuan hutang. Karena grosse akta pengakuan hutang yang dibuat dihadapan notaris mempunyai kekuatan hukum yang sama seperti halnya dengan putusan pengadilan yang sudah mempunyai kekuatan hukum tetap. Sebagaimana dalam pembuatan akta pengakuan hutang yang dibuat secara notariil, pada kepala dokumen/suratnya telah dicantumkan irahirah "DEMI KEADILAN BERDASARKAN KETUHANAN YANG MAHA ESA", yang dimaknai sebagai sumpah yang mengatas namakan Tuhan. Sehingga sesuai dengan manfaat eksekusi pada grosse akta yang menyelesaikan hutangnya dengan cepat, efektif dan tidak menghabiskan banyak waktu.

\footnotetext{
${ }^{49}$ Rivi Kurniawan, loc.cit.
} 
E. Kesimpulan dan Saran

1. Kesimpulan

Berdasarkan uraian yang telah dikemukakan pada bab sebelumnya, maka pada bab ini di ambil kesimpulan sebagai berikut:

a. Kekuatan hukum eksekusi akta pengakuan hutang dalam perjanjian kredit sudah dapat dilaksanakan sebagaimana mestinya. Karena akta pengakuan utang yang dibuat oleh notaris dengan memberikan grosse akta mempunyai kekuatan hukum yang sama seperti halnya dengan putusan pengadilan yang sudah mempunyai kekuatan hukum tetap. Oleh karenanya, pembuatan surat pengakuan utang yang dibuat secara notariil, pada kepala dokumen/suratnya harus dicantumkan kalimat "Demi Keadilan Berdasarkan Ketuhanan Yang Maha Esa", yang dimaknai sebagai sumpah yang mengatas namakan Tuhan.

b. Akibat hukum terhadap debitur dalam akta pengakuan hutang apabila terjadi wanprestasi dalam perjanjian kredit adalah maka jaminan akta pengakuan hutang dapat langsung di eksekusi oleh pihak kreditur atau Bank. Sehingga pihak debitur harus bersedia melepaskan hak atas jaminan akta pengakuan hutang dengan memberikan kekuasaan kepada pihak bank untuk dapat melunasi utangnya tersebut.

c. Upaya hukum dalam eksekusi grosse akta pengakuan Hutang dalam Perjanjian Kredit dengan melakukan penyelamatan kredit. Pihak kreditur atau Bank tidak langsung melakukan eksekusi terhadap jaminan akta pengakuan hutang tersebut, pihak Bank membuat surat pernyataan kerelaan pelepasan hak atas yang dijaminkan debitur tersebut dan meminta debitur untuk menandatangani surat tersebut, pihak kreditur masih menghindari upaya eksekusi, karena utang debitur yang tersisa sebagian menurut perhitungan utang pokok menjadi alasan ditundanya eksekusi atas objek jaminan akta pengakuan hutang oleh pihak kreditur. Oleh sebab itu, pihak kreditur memberikan kebijakan kepada debitur untuk melunasi utangnya dengan cara menambah jangka waktu pelunasan dengan cicilan yang lebih rendah.

\section{Saran}

a. Disarankan kepada pihak kreditur atau Bank agar tidak perlu lagi untuk membuat surat pernyataan sukarela 
melepaskan hak atas jaminan akta pengakuan hutang, karena dengan adanya grosse akta pengakuan hutang kekuatan hukum eksekusi tersebut sama dengan putusan pengadilan.

b. Disarankan kepada Debitur agar lebih berhati-hati dan mempelajari segala akibat dan resiko dalam melakukan perjanjian kredit untuk memberikan jaminanya yang dibuat dalam akta pengakuan hutang.

c. Disarankan kepada notaris sebaiknya memberikan penjelasan mengenai kekuatan eksekusi grosse akta pengakuan hutang kepada kreditur dan debitur serta akibat hukum yang timbul dari grosse akta pengakuan hutang dalam perjanjian kredit.

\section{F. DAFTAR PUSTAKA}

\section{Buku}

Ali, Zainuddin. 1997. Metode Penelitian Hukum. Jakarta: , Raja Grafindo Persada.

Bungin, Burhan. 2004. Analisis Data Penelitian Kualitatif, Pemahaman Filosofis Dan Metodologis Kearah Penguasaan Modal Aplikasi. Jakarta: Raja Grafindo Persada.

Darus, Mariam Badrulzaman. 1991. Perjanjian Kredit Bank. Bandung: Citra Aditya.

M. Febby Sukatendel. 2009. Panduan Bantuan Hukum di Indonesia; pedoman anda memahami dan menyelesaikan masalah hukum
(Kredit dan Masalah Keuangan). Jakarta: YLBHI.

Marwali. Rachman, 2021. Pembatalan APHT Akibat Tidak Berwenangnya Debitur Pemberi Hak Tanggungan. Jakarta: Bumi Aksara.

Johan, Nasution Bahder. 2008. Metode Penelitian Ilmu Hukum. Bandung: Mandar Maju.M.Yahya Harahap. 2006. Ruang Lingkup Permasalahan Eksekusi Bidang Perdata. Jakarta: Sinar Grafika.

R. Subekti. 1995. Aneka Perjanjian. Intermasa, Bandung: Intermasa.

--------. 2007. Kitab Undang-Undang Hukum Perdata. Jakarta: Arga Printing.

Ricardo Simanjuntak. 2011. Teknik Perancangan Perjanjian Bisnis. Jakarta: Kontan Publishing.

Riduan Tobink dan Bill Nikholaus. 2003. “Kamus Istilah Perbankan”. Jakarta: Atalya Rileni Sudeco.

Victor M. Situmorang dan Cormentyna Sitanggang. 1998. Grosse Akta dalam Pembuktian dan Eksekusi. Jakarta: Rineka Cipta.

\section{Peraturan Perundang-Undangan}

Kitab Undang-Undang Hukum Perdata Undang-Undang Republik Indonesia Nomor 4 Tahun 1996 tentang Hak Tanggungan.

Undang-Undang Republik Indonesia Nomor 2 Tahun 2014 tentang Perubahan Atas Undang-Undang Republik Indonesia Nomor 30 Tahun 2004 tentang Jabatan Notaris.

\section{Jurnal/Artikel/Putusan}


Dwiyanti, Riny Manaroinsong. 2012. Kedudukan Hukum Surat Kuasa Menjual Terhadap Objek Jaminan Yang Dibebani Dengan Hak Tanggungan, Tesis, Program Kenotariatan, Fakultas Hukum, Universitas Hasanuddin.

Jaya, Saraswati. 2010. Perlindungan Hukum Terhadap Bank Sebagai Kreditor Pemegang Hak Tanggungan Dalam Penangguhan Eksekusi Jaminan Berkaitan Dengan Undang-Undang Nomor 37 Tahun 2004 Tentang Kepailitan, Tesis, Program Kenotariatan, Fakultas Hukum, Universitas Sumatera Utara.

Justinus, Hamonangan Gultom dan Erna Susilawaty Sebayang, "Aspek Hukum Akta Pengakuan Hutang Dalam Perjanjian Kredit Konsumtif", Jurnal Ilmiah Skylandsea, ISSN: 2614-5154. Volume 2 No. 1 Februari 2018.

Santoso, Didi. 2009. "Tanggung Jawab Notaris Dalam Pembuatan Akta Yang Memuat Dua Perbuatan Hukum (Analisis Putusan Mhkamah Agung Nomor 1440.K/Pdt/1996)." Tesis, Universitas Diponegoro, Semarang,.

Suyitno, Salawati 2007. "Analisis Yuridis Terhadap Eksekusi Benda Jaminan yang Dibebani Hak Tanggungan Pada Debitur Pailit", Tesis, Universitas Sumatera Utara, Medan.

Tarigan, Ermalisa. Eksekusi barang Jaminan oleh Bank dalam Penyelesaian Kredit Macet (Studi Kasus Pada Bank "D” di Medan), Tesis, Program Kenotariatan, Universitas Sumatera Utara, h. 16.

Vianni, Shendy Rangian, "Pelaksanaan Eksekusi Grosse Akta Pengakuan Hutang dalam Penyelesaian Sengketa Kredit Macet Perbankan",
Jurnal Ilmiah Mahasiswa Universitas Surabaya Voume 4, Nomor 1, 2015. 